\title{
Structure and Properties of Zn-Mg Alloys for Medical Implants
}

Iva Pospisilova, Dalibor Vojtech, Jiri Kubasek

Department of Metals and Corrosion Engineering, Institute of Chemical Technology in Prague, Technicka 5, Prague 6, 166 28, Czech Republic. Email: pospisii@vscht.cz

Polymeric materials are used in modern medicine for the fixation of fractured bones. Their function is only temporary - they serve as substitutes till they are replaced by human tissue (without additional reoperation). Their disadvantage is that they possess low mechanical strength and hardness. As an alternative to polymeric materials, the metallic fixation components are being developed. Their advantage is the higher value of strength, toughness and hardness. Zinc alloys represent a new trend in this technological field. They also meet the requirements for biocompatibility and their mechanical properties approach the properties of human bones. In this paper, the structural and mechanical characteristics are described. The only alloying element in the zinc alloys examined was magnesium in the range $0-8.3 \mathrm{wt}$. \%. The mechanical properties were discussed in the relation to the microstructure and the phase composition of the alloys. The results showed that the mechanical properties of binary $\mathrm{Zn}-\mathrm{Mg}$ alloys increase with the growing content of $\mathrm{Mg}$ with the maximum achieved at the eutectic composition. Higher magnesium content strongly deteriorates the mechanical properties of these alloys.

Keywords: Biodegradable material, Zinc, Mechanical properties, Structure

Acknowledgement

Research of the biodegradable metallic materials is financially supported by the Czech Science Foundation (project no.P108/12/G043).

\section{References}

[1] VALÁŠEK, P.,MÜLLER, M. (2012). Polymeric particle composites with filler saturated matrix. In: Manufacturing Technology m, Vol.12, pp.272-276.

[2] WITTE, F. (2010). The history of biodegradable magnesium implants: A review. In: Acta Biomaterialiam, Vol.6, pp.1680-1692.

[3] HiROMOTO, S., SHISHIDO, T., YAMAMOTO, A., MARUYAMA, N., SOMEKAWA, H., and MUKAI, T. (2008). Precipitation control of calcium phosphate on pure magnesium by anodization. In: Corrosion Sciencem, Vol.50, pp.2906-2913.

[4] ZHANG, C.Y., ZENG, R.C., LIU, C.L., and GAO, J.C. (2010). Comparison of calcium phosphate coatings on $\mathrm{Mg}-\mathrm{Al}$ and Mg-Ca alloys and their corrosion behavior in Hank's solution. In: Surface \& Coatings Technologym, Vol.204, pp.3636-3640.

[5] PEREDA, M.D., ALONSO, C., BURGOS-ASPERILlA, L., DEL VALLE, J.A., RUANO, O.A., PEREZ, P., and FERNANDEZ LORENZO DE MELE, M.A. (2010). Corrosion inhibition of powder metallurgy Mg by fluoride treatments. In: Acta Biomaterialiam, Vol.6, pp.1772-1782.

[6] GU, X.N., ZHENG, W., CHENG, Y., and ZHENG, Y.F. (2009). A study on alkaline heat treated Mg-Ca alloy for the control of the biocorrosion rate. In: Acta Biomaterm, Vol.5, pp.2790-9.

[7] WITTE, F., HORT, N., VOGT, C., COHEN, S., KAINER, K.U., WILlUMEIT, R., and FEYERABEND, F. (2008). Degradable biomaterials based on magnesium corrosion. In: Current Opinion in Solid State and Materials Sciencem, Vol.12, pp.63-72.

[8] ZHANG, E., YANG, L., XU, J., and CHEN, H. (2010). Microstructure, mechanical properties and bio-corrosion properties of Mg-Si(-Ca, Zn) alloy for biomedical application. In: Acta Biomaterm, Vol.6, pp.1756-62.

[9] HUAN, Z.G., LEEFLANG, M.A., ZHOU, J., FRATILA-APACHITEI, L.E., and DUSZCZYK, J. (2010). In vitro degradation behavior and cytocompatibility of Mg-Zn-Zr alloys. In: Journal of Materials Science-Materials in Medicinem, Vol.21, pp.2623-2635.

[10] LI, Z., GU, X., LOU, S., and ZHENG, Y. (2008). The development of binary Mg-Ca alloys for use as biodegradable materials within bone. In: Biomaterialsm, Vol.29, pp.1329-1344.

[11] VOJTECH, D., KUBASEK, J., SERAK, J., and NOVAK, P. (2011). Mechanical and corrosion properties of newly developed biodegradable Zn-based alloys for bone fixation. In: Acta Biomaterialiam, Vol.7, pp.3515-3522. 
[12] GALE, W.F., TOTEMEIER, T.C., and SMITHELLS, A., (2004).Metals Reference Book: Elsevier Publishers.

[13] LI, Q.-F., WENG, H.-R., SUO, Z.-Y., REN, Y.-L., YUAN, X.-G., and QIU, K.-Q. (2008). Microstructure and mechanical properties of bulk $\mathrm{Mg}-\mathrm{Zn}-\mathrm{Ca}$ amorphous alloys and amorphous matrix composites. In: Materials Science and Engineering: Am, Vol.487, pp.301-308.

[14] GU, X., ZHENG, Y., ZHONG, S., XI, T., WANG, J., and WANG, W. (2010). Corrosion of, and cellular responses to Mg-Zn-Ca bulk metallic glasses. In: Biomaterialsm, Vol.31, pp.1093-1103.

[15] ZBERG, B., UGGOWITZER, P.J., and LOEFFLER, J.F. (2009). MgZnCa glasses without clinically observable hydrogen evolution for biodegradable implants. In: Nature Materialsm, Vol.8, pp.887-891.

[16] VOJTĚCH, D., KUBÁSEK, J., and VODĚROVÁ, M. (2012). Structural, mechanical and in vitro coorosion characterization of as-cast magnesium based alloys for temporary biodegradable mical implants. In: Manufacturig Technology m, Vol.12, pp.285-292.

[17] CZAJKOWSKA A, K.P., WCIŚLIK W, STASIAK-BETLEJEWSKA R. (2013). Application of Electron Scanning Microscope in the Analysis of Structure of Casting Non-Conformities Aimed at Optimization of Technological Process Parameters. In: Manufacturig Technology m, Vol.13, pp.164-169. 